\title{
Initial in situ measurements of perennial meltwater storage in the Greenland firn aquifer
}

\author{
Lora S. Koenig, ${ }^{1}$ Clément Miège, ${ }^{2}$ Richard R. Forster, ${ }^{2}$ and Ludovic Brucker ${ }^{1,3}$ \\ Received 10 October 2013; revised 25 November 2013; accepted 27 November 2013.
}

[1] A perennial storage of water in a firn aquifer was discovered in southeast Greenland in 2011. We present the first in situ measurements of the aquifer, including densities and temperatures. Water was present at depths between $\sim 12$ and $37 \mathrm{~m}$ and amounted to $18.7 \pm 0.9 \mathrm{~kg}$ in the extracted core. The water filled the firn to capacity at $\sim 35 \mathrm{~m}$. Measurements show the aquifer temperature remained at the melting point, representing a large heat reservoir within the firn. Using model results of liquid water extent and aquifer surface depth from radar measurements, we extend our in situ measurements to the Greenland ice sheet. The estimated water volume is $140 \pm 20 \mathrm{Gt}$, representing $\sim 0.4 \mathrm{~mm}$ of sea level rise (SLR). It is unknown if the aquifer temporary buffers SLR or contributes to SLR through drainage and/or ice dynamics. Citation: Koenig, L. S., C. Miège, R. R. Forster, and L. Brucker (2014), Initial in situ measurements of perennial meltwater storage in the Greenland firn aquifer, Geophys. Res. Lett., 41, doi:10.1002/2013GL058083.

\section{Introduction}

[2] Mass loss from the Greenland ice sheet (GrIS) is accelerating at a rapid pace [Shepherd et al., 2012; Hanna et al., 2013]. In the last decade, surface mass balance processes, dominated by meltwater from the ice sheet, account for over half of the mass loss [van den Broeke et al., 2009]. Very little, however, is known about the quantity of meltwater that flows through the hydrologic system, its pathways, or the rates of refreezing and retention that occur as the meltwater travels toward the sea [Harper et al., 2012; Humphrey et al., 2012; van Angelen et al., 2013]. Studies of meltwater retention and refreezing in firn are limited in number and location mostly to Western Greenland [Bøggild et al., 2005; Humphrey et al., 2012; Harper et al., 2012; Rennermalm et al., 2013] though simulations show that $42 \pm 4 \%$ of rain and meltwater is either retained or refrozen in the firn without reaching the sea [van Angelen et al., 2013]. Only recently, meltwater was observed to be stored in the firn over the winter in a large $\left(70 \pm 10 \times 10^{3} \mathrm{~km}^{2}\right)$ firn

Additional supporting information may be found in the online version of this article.

${ }^{1}$ Cryospheric Sciences Laboratory, NASA Goddard Space Flight Center, Greenbelt, Maryland, USA.

${ }^{2}$ Department of Geography, University of Utah, Salt Lake City, Utah, USA.

${ }^{3}$ Goddard Earth Sciences Technology and Research Studies and Investigations, Universities Space Research Association, Columbia, Maryland, USA.

Corresponding author: L. S. Koenig, Cryospheric Sciences Laboratory, NASA Goddard Space Flight Center, Greenbelt, MD 20771, USA. (lora.s.koenig@nasa.gov)

C2013. American Geophysical Union. All Rights Reserved. 0094-8276/14/10.1002/2013GL058083 aquifer, concentrated in Southeast Greenland where both accumulation and melt rates are high [Burgess et al., 2010; Forster et al., 2013]. The firn aquifer is a perennial storage of water at depth, between 5 and $50 \mathrm{~m}$ below the surface, controlled by local topography, seasonal snowpack thickness, and melting and refreezing rates. Firn aquifer analogs are found in temperate glaciers [e.g., Fountain, 1989] and ice caps [e.g., de Woul et al., 2006], but the Greenland aquifer is deeper, larger, and subsists year after year [Forster et al., 2013]. Here we present the first density and temperature profiles associated with the Greenland firn aquifer; we estimate the volume of water stored and discuss its implications for sea level rise (SLR) in terms of the ice sheet mass budget and water retention.

\section{Field Measurements and Analysis}

[3] During the first 10 days of April 2013, we took in situ measurements of the aquifer at a site, FA13 $\left(66.1812^{\circ} \mathrm{N}\right.$, $39.0435^{\circ} \mathrm{W}, 1563 \mathrm{~m}$ above sea level (asl)), located between the two Arctic Circle Traverse (ACT) core sites (ACT11-A and ACT11-A2) where the water-saturated firn was first observed (Figure 1) [Forster et al., 2013]. The ACT traverses, conducted in the spring of 2010 and 2011, measured accumulation rates in the high-accumulation region of SE Greenland using a $400 \mathrm{MHz}$ ground-penetrating radar and firn cores [Miège et al., 2013]. The closest seasonally dry firn core to our site is ACT11-B $\left(66.2174^{\circ} \mathrm{N}, 39.5658^{\circ} \mathrm{W}, 1806 \mathrm{~m}\right.$ asl), located $\sim 24 \mathrm{~km}$ West of our site and $\sim 7.5 \mathrm{~km}$ West of the lateral edge of the firn aquifer. ACT11-B, referred to as the dry firn core, has well-defined melt layers throughout the $60 \mathrm{~m}$ core comprising $\sim 17 \%$ of the core length. At site FA13, the water layer was mapped by radar in 2011 to be close to the surface at a depth of $15 \mathrm{~m}$. Two cores, FA13-A and FA13-B, located $2 \mathrm{~m}$ apart, were drilled from the surface to depths of $60.4 \mathrm{~m}$ and $32.0 \mathrm{~m}$, respectively, into the aquifer to measure water level, density, and temperature. A mechanical drill was used in the seasonally dry firn above the water table (upper $\sim 10 \mathrm{~m}$ ), and an electrothermal drill was used to drill through the saturated firn.

\subsection{Density Measurements}

[4] Figure 2a shows the gravimetric density profiles from cores FA13-A and FA13-B at $\sim 20 \mathrm{~cm}$ vertical resolution and from the closest seasonally dry firn core, at $\sim 1 \mathrm{~m}$ vertical resolution. (Densities were measured to a depth of $50.5 \mathrm{~m}$ in FA13-A.) Measurement errors of $\pm 5 \%$ are assumed due to core volume irregularities. Additional unquantifiable density errors are introduced when water drains from the saturated firn cores during extraction and handling, giving a low bias to all densities with water saturation (see supporting information). Density profiles of the seasonally dry firn above the water table (top $\sim 12 \mathrm{~m}$ ) mimic that of the closest dry firn core and clearly show higher-density layers characteristic of 


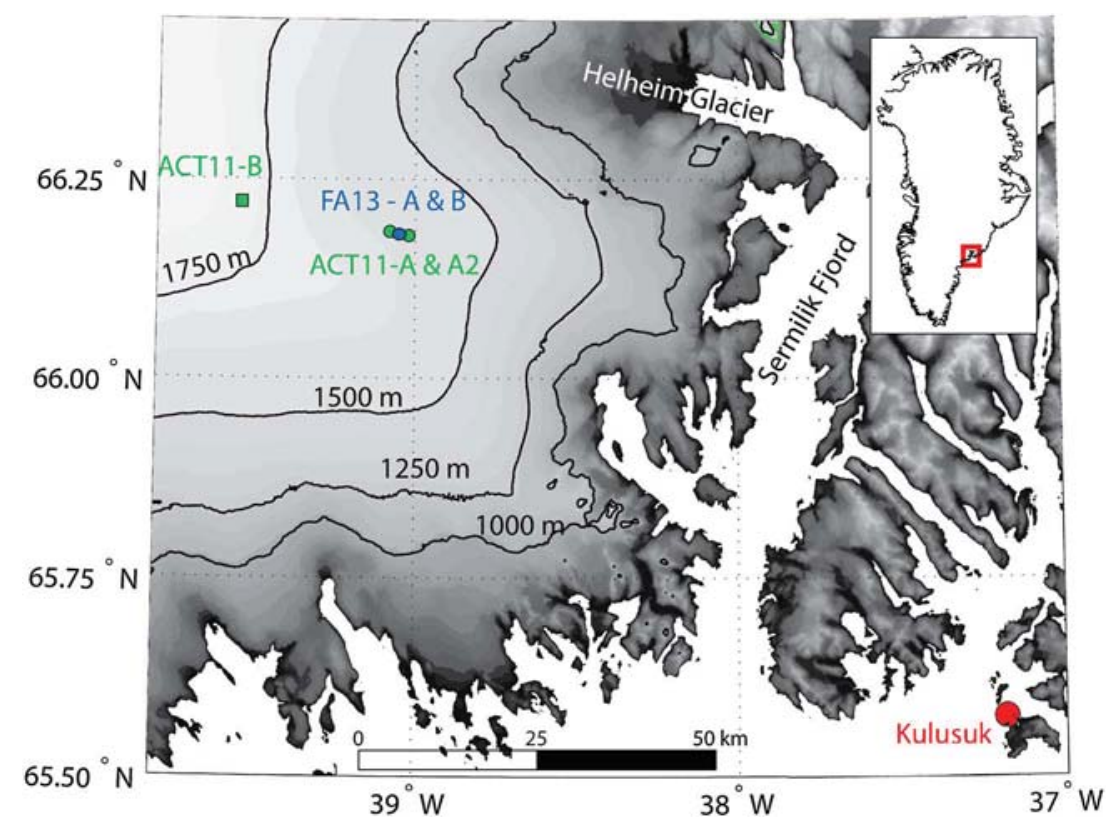

Figure 1. Map of 2013 study area. Cores FA13-A and FA13-B (blue circles) are located between ACT11-A and ACT11-A2 (green circles) where the water table was first observed. ACT11-B (green square) is the closest dry firn core. Elevation from Howat et al. [2013].

infiltrated water from summer melt or rain and subsequent refreezing. Starting at $\sim 8 \mathrm{~m}$ below the surface, the seasonally dry firn has a very well-connected percolation drainage network evident by piping structures seen within the core (Figure S1 in the supporting information). Water was first encountered at a depth of $12.2 \pm 0.1 \mathrm{~m}$ in both boreholes. Water immediately filled the boreholes $(\sim 12 \mathrm{~cm}$ diameter) below $12.2 \mathrm{~m}$ (Figure S2) and remained at this level over the 4 day sampling period. When the second borehole (FA13-B) was drilled, the water level did not change in FA13-A, implying that the firn aquifer is unconfined [Fountain, 1989] and gravitationally fed by surface meltwater.

[5] Core segments between $12.2 \mathrm{~m}$ and $36.9 \mathrm{~m}$ were composed of a mixture of well-bonded firn and well-connected pore space either filled or partially filled with water evident by the densities above that of ice (Figure 2). FA13-A and FA13-B density profiles were nearly identical and were combined into a single-FA13 density profile for further analysis (see Figure 2 and supporting information for details). Due to the lack of an adequate depth densification model for the percolation zone with water-saturated firn, two fits were used in our analysis. The measured densities were fitted with an exponential curve introduced by Hörhold et al. [2011] (Figure 2a) and a modified Herron and Langway (HL) fit [Herron and Langway, 1980] (Figure 2b). The HL fit is empirically based for dry snow compaction; however, here only the form of the equation is maintained. The critical ice density, point at which recrystallization and deformation are the dominant densification processes, was allowed to vary. Therefore, in this melt-/freeze-dominated environment the model parameters based on dry snow processes have no physical meaning (i.e., the best fit mean annual temperature and accumulation are not reasonable for this location on the ice sheet). Both fits were adjusted by minimizing the root-mean-square error (RMSE) and were nearly identical in fit (exponential fit, $\mathrm{RMSE}=43.7 \mathrm{~kg} / \mathrm{m}^{3}$ and $\mathrm{HL}$ fit, $\left.\mathrm{RMSE}=44.3 \mathrm{~kg} / \mathrm{m}^{3}\right)$. The exponential fit was used in our analysis because it includes an additional exponential term over HL fit, thus allowing more flexibility in representing the measurements.

[6] While we had no direct way of quantitatively determining pore close-off depth in the field, we used the simple techniques of manually blowing air into the $20 \mathrm{~cm}$ core sections, visual inspection, and visible photography. We estimated a pore close-off depth between 33 and $35 \mathrm{~m}$ (Figure 2a). In dry firn conditions pore close-off is defined as $\sim 830 \mathrm{~kg} / \mathrm{m}^{3}$ [Cuffey and Paterson, 2010], which is the density at which air bubbles become entrapped in the ice. However, with water-saturated firn, where densities are often over $900 \mathrm{~kg} / \mathrm{m}^{3}$ (Figures 2 and S3) [Fountain, 1989], a new metric is needed to define the lower boundary of the firn aquifer. We define the pore water refreeze depth as the depth where water in the pore space produces a maximum density; below this depth the water in the pore space refreezes, causing a gradual decrease in density to the density of ice. The pore water refreeze depth occurs at $36.9 \mathrm{~m}$ determined by the exponential fit (Figure 2a). At this depth the maxima-fitted density $\left(915 \mathrm{~kg} / \mathrm{m}^{3}\right)$ is reached and densities below this depth show that the small amounts of entrapped water are refreezing to ice. We define the bottom of the firn aquifer as the pore water refreeze depth (rounded to $37 \mathrm{~m}$ ). Though it is certain that small amounts of water exist below our defined bottom of the firn aquifer, it is refreezing to ice.

\subsection{Temperature Measurements}

[7] Thermistor strings with $0.5 \mathrm{~m}$ and $2.5 \mathrm{~m}$ spacing between sensors were inserted in the FA13-B and FA13-A boreholes, respectively; each borehole was backfilled using fine surface snow, and the thermistors were left to record subdaily temperature profiles for a year or longer. Figure 3 shows the $0.5 \mathrm{~m}$ temperature profiles from the FA13-B borehole. The surface of the water table is easily distinguishable at $\sim 12 \mathrm{~m}$ with a constant $0.1 \pm 0.1^{\circ} \mathrm{C}$ temperature recorded from this point to the bottom of the thermistor string. The temperatures 

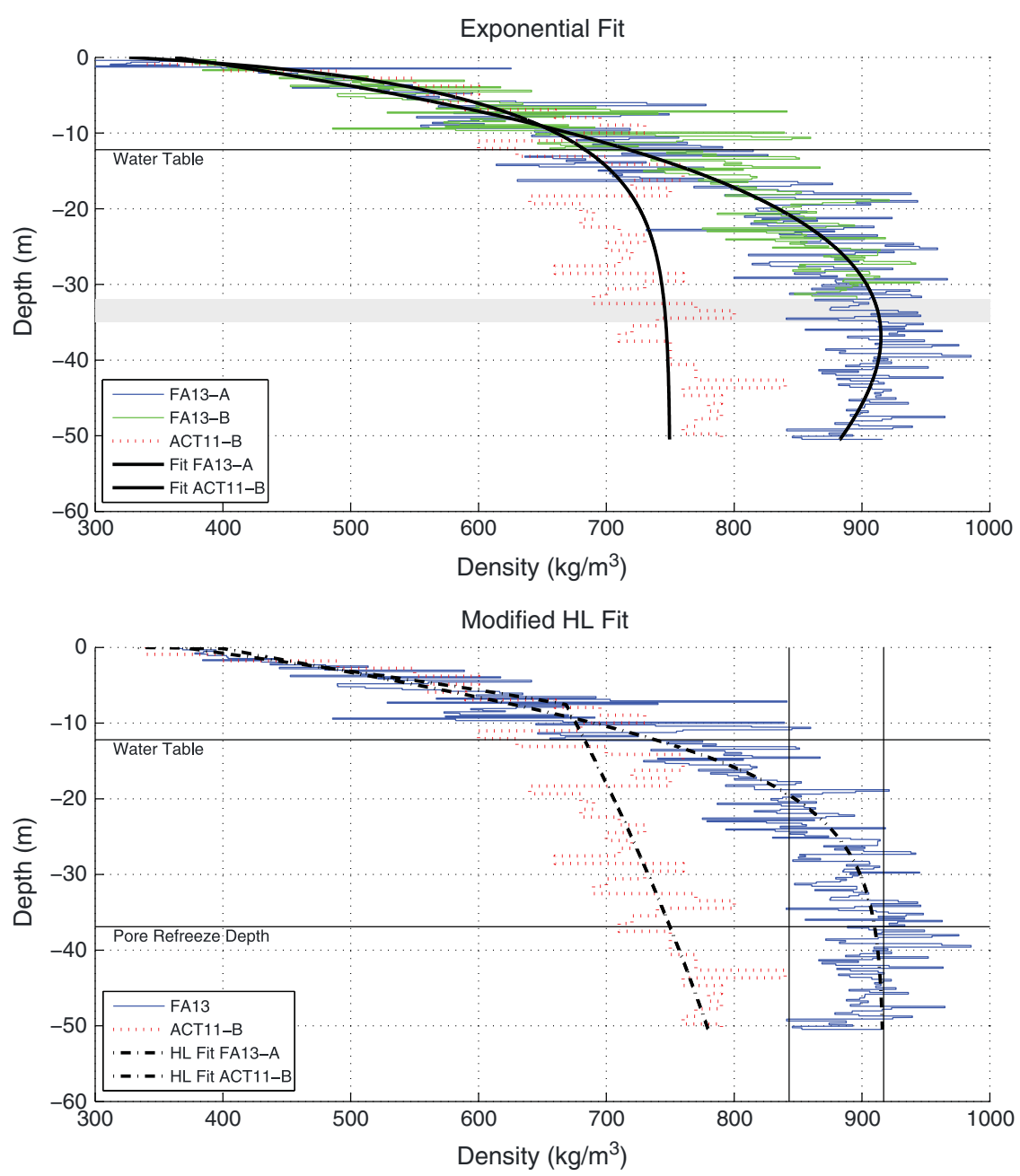

Figure 2. (a) Density profiles from ACT11-B, FA13-A, and FA13-B with exponential fits [Hörhold et al., 2011]; gray area is the field-observed pore close-off depth, and horizontal black line is the surface of the water table. (b) Density profiles from ACT11-B and combined FA13 with a modified Herron and Langway [1980] fit. The horizontal lines show the surface of the water table and the pore water refreeze depth. The black vertical lines from left to right represent the infiltration ice density [Harper et al., 2012] and ice density.

measured are indistinguishable from the melting point and assumed $0^{\circ} \mathrm{C}$ with both water and ice present. In contrast, temperatures recorded in the seasonally dry firn above the water table show surface-forced warming in the spring/summer. The first surface-melting events were recorded on 10 June 2013. The temperature profiles highlight the temperate water/ice conditions at depth, much warmer than expected for the region. The aquifer, through water percolation and phase changes, represents a heat reservoir in the GrIS which is not currently accounted for in firn models.

\subsection{Annual Stability of the Water Table Elevation}

[8] Annual variations in the depth of the water table surface were measured from 2011 to 2013 using ground-based and airborne radars, center frequency of $400 \mathrm{MHz}$ and $750 \mathrm{MHz}$, respectively (Table 1). For this assessment we use only the depths calculated from radar measurements and ice sheet surface elevations. We neglect change from variations in firn compaction and ice flow. The accuracy of the radar-derived depths is $\pm 0.3 \mathrm{~m}$ based on the vertical resolution of the radars. These data show a constant surface elevation of the water table at this location from 2011 to 2012. In 2013, the water surface elevation rose by $0.7 \pm 0.3 \mathrm{~m}$, coinciding with a surface lowering of $2 \mathrm{~m}$. This occurs after the 2012 extreme summer melt over the GrIS [Nghiem et al., 2012; Hall et al., 2013]. While the time series is short, 3 years, the annual variation of the water table surface, as summarized in Table 1, shows that between April 2012 and April 2013 the aquifer likely filled caused by the intense melt season and identified by the rise in water table.

Table 1. Annual Variations of Water Table Surface

\begin{tabular}{lccc}
\hline $\begin{array}{l}\text { Radar Data } \\
\text { Collection } \\
\text { Date }\end{array}$ & $\begin{array}{c}\text { Surface } \\
\text { Elevation (m) }\end{array}$ & $\begin{array}{c}\text { Water Table Depth } \\
\text { From Surface (m) }\end{array}$ & $\begin{array}{c}\text { Water Table } \\
\text { Surface Elevation (m) }\end{array}$ \\
\hline 2 May 2011 & 1565.5 & 15.0 & 1550.5 \\
17 April 2012 & $1565.6^{\mathrm{a}}$ & $15.1^{\mathrm{b}}$ & 1550.5 \\
3 April 2013 & 1563.5 & 12.3 & 1551.2 \\
\hline
\end{tabular}

${ }^{\mathrm{a}}$ From Airborne Topographic Mapper data [Krabill, 2012].

${ }^{\mathrm{b}}$ From Accumulation Radar data [Leuschen, 2012]. 


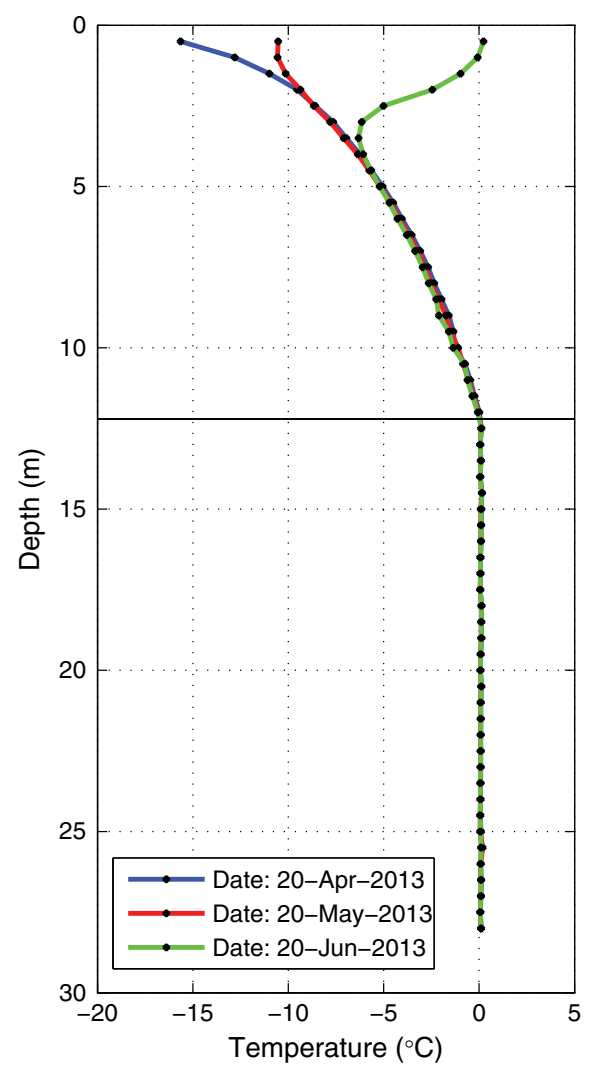

Figure 3. Daily averaged temperature profiles from FA13-B borehole. The horizontal black line represents the surface of the water table. Each thermistor is represented by a black dot.

\section{Water Saturation and Implications for Sea Level Rise}

[9] To approximate the volume of stored water from the new cores, it is assumed that the pore space available for water saturation is equal to the pore space calculated from the closest dry firn density profile and that the density difference between the water-saturated core and the dry core is attributed to water (see supporting information). Figure 4 shows the percentage of pore space available for water saturation and the percentage of water at this site. At $33.5 \mathrm{~m}$ the percentage of water and percentage of available pore space overlap, showing complete saturation of the firn, $\sim 3.5 \mathrm{~m}$ above the pore refreeze depth. The field-estimated pore close-off depth $(33-35 \mathrm{~m})$ overlaps with water saturation where compaction and water had likely decreased the ability for air to move through the core.

[10] The water table is $24.7 \mathrm{~m}$ thick at this location, and the core contained $18.7 \pm 0.9 \mathrm{~kg}$ of water, from its water-saturated surface to the pore water refreeze depth. The firn aquifer surface mapping done by Forster et al. [2013] showed a Gaussian distribution of depths with a mean of $23 \mathrm{~m}$. Assuming that the bottom of the entire aquifer is constant and stable at $37 \mathrm{~m}$ depth, this gives a mean thickness of $14 \mathrm{~m}$ with a two sigma thickness range of 0 to $28 \mathrm{~m}$. We calculate the total volume of the water-saturated aquifer, using the mean thickness $(14 \mathrm{~m})$ and the modeled area over the GrIS ice sheet $\left(70 \pm 10 \times 10^{3} \mathrm{~km}^{2}\right)$ [Forster et al., 2013], to be $980 \pm 140 \mathrm{~km}^{3}$. Assuming the same density of water measured at the core site throughout the entire firn aquifer, the total estimated amount of water stored in the aquifer throughout the ice sheet is $140 \pm 20 \mathrm{Gt}$, which represents $\sim 0.4 \mathrm{~mm}$ of SLR.

[11] It is unknown from our measurements if the stored water is connected to the ice sheet basal hydrology or if it has any pathways to drain into the ocean. Two hypotheses present possible pathways for this stored water to exit the aquifer. (1) The aquifer is connected to a well-developed englacial hydrologic network, including crevasses and moulins that drain some portion of the aquifer at a relatively constant rate (seasonally) to the bed, similar to surface melt in Western Greenland [e.g., Zwally et al., 2002]. This hypothesis assumes that the water table has persisted over a long enough time scale to develop a hydrologic network. Additional studies on water residence time, flow paths and rates, and volume input are required to favor this hypothesis as well as a connection to crevasses in the region which has not yet been found. Or (2) the aquifer is primarily storing water in available firn pore space and will not release water until the pore space is completely saturated and/or a threshold is met, leading to a catastrophic release event, similar to jokulhlaups [e.g., Nye, 1976]. The second hypothesis is supported by our initial measurements showing available pore space (Figure 4) and a rise in the water table after record surface melting (Table 1). These hypotheses are not independent, and both scenarios need additional study. The firn aquifer likely plays a significant role in SLR by either accelerating glacial flow in the region and/or by storing and then catastrophically supplying large amounts of fresh water if connected to the ocean.

\section{Firn Capacity Within Firn Aquifer Regions}

[12] Assuming the second hypothesis, the firn aquifer may serve as a long-term reservoir for meltwater that temporarily buffers SLR. Harper et al. [2012] used firn capacity (in $\mathrm{kg} / \mathrm{m}^{2}$ ) to quantify the capacity of the GrIS to buffer SLR by storing percolated meltwater in the firn that refroze. While the calculations done by Harper et al. [2012] are valid for most of the percolation zone, it is clear that in regions of high accumulation and high melt rates, like those in southeast Greenland where the PFA has been mapped,

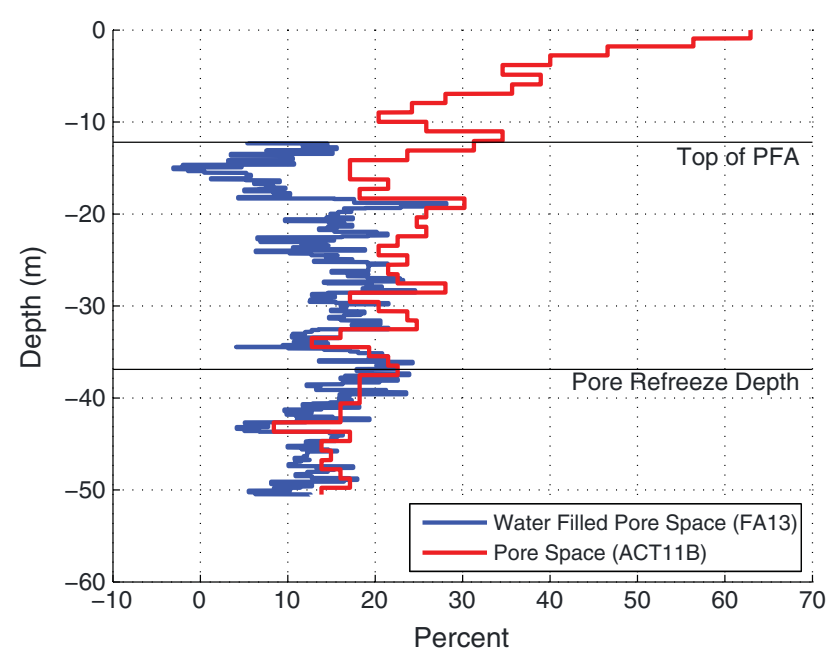

Figure 4. Percent of pore space (ACT11-B) and percent of water (FA13) assuming equivalent firn porosity between the dry and water-filled cores. 
Harper et al.'s [2012] capacity calculation must be adjusted for water retention which adds capacity. After adjusting calculations in aquifer regions, water storage represents an increase of $8.9 \%$ over regions of refrozen meltwater due to the difference in density between water and ice (see supporting information for details and Figure S4). Firn aquifer regions, therefore, allow for additional storage of meltwater, and therefore a larger SLR buffer than accounted for by Harper et al. [2012]. Though the firn aquifer can store more meltwater, the site studied is already filled to $50 \%$ of its capacity compared to the nearby seasonally dry location (see supporting information and Figure S5). Firn capacity is reached at $\sim 35 \mathrm{~m}$ showing that the bottom of the aquifer has reached full capacity. Future meltwater must continue filling the upper portion of the aquifer until either the firn is full, no longer allowing percolation of surface melt, forcing melt to flow directly to the ocean or a tipping point is reached where the stored water catastrophically releases [e.g., Nye, 1976].

\section{Conclusion}

[13] The perennial firn aquifer is large gravitationally fed liquid water body in the GrIS. At our study site the top of the water table is at $12.2 \mathrm{~m}$ and water extends for $24.7 \mathrm{~m}$ to the pore water refreeze depth at $36.9 \mathrm{~m}$, though small amounts of water do exist below this depth. A longer time series is needed to confidently correlate depth variations in the water table surface with specific melt and accumulation events, though there is evidence of a rise in the water table after the extreme summer melt of 2012. It is unknown if the firn aquifer is currently buffering SLR, with an additional $8.9 \%$ storage over other percolation regions, or if the firn aquifer episodically accelerates SLR by influencing ice dynamics or periodically draining to the ocean.

[14] Indeed, quantitative measurements of water saturation, flow velocity, and permeability are needed to better characterize the water volume at several additional sites across the firn aquifer. Further studies and modeling of the firn aquifer are also needed to fully understand its impact on SLR and to improve future predictions. These initial measurements do show that the volume of liquid water storage in SE Greenland is large. With an estimated $\sim 0.4 \mathrm{~mm}$ contribution to SLR contained in the firn aquifer, it is an important source of previously neglected heat and water storage in the GrIS.

[15] Acknowledgments. The authors thank J. Kyne at IDDO, S. Zager at $\mathrm{CH} 2 \mathrm{MHill}$ PFS for logistical assistance, and T. Neumann for his discussions. The authors also thank the anonymous reviewers for their comments that improved the manuscript. This work was supported by NSF grant 1311655 and the NASA Cryospheric Sciences, NIP and ESS programs.

[16] The Editor thanks two anonymous reviewers for their assistance in evaluating this paper.

\section{References}

Bøggild, C. E., R. Forsberg, and N. Reeh (2005), Meltwater retention in a transect across the Greenland ice sheet, Ann. Glaciol., 40(1), 169-173, doi: $10.3189 / 172756405781813546$.
Burgess, E. W., R. R. Forster, J. E. Box, E. Mosley-Thompson, D. H. Bromwich, R. C. Bales, and L. C. Smith (2010), A spatially calibrated model of annual accumulation rate on the Greenland Ice Sheet (1958-2007), J. Geophys. Res., 115, F02004, doi:10.1029/ 2009JF001293.

Cuffey, K. M., and W. S. B. Paterson (2010), The transformation of snow to ice, in Physics of Glaciers, 4th ed., pp. 11-28, Butterworth-Heinemann, Burlington, Mass.

de Woul, M., R. Hock, M. Braun, T. Thorsteinsson, T. Jóhannesson, and S. Halldórsdóttir (2006), Firn layer impact on glacial runoff: A case study at Hofsjökull, Iceland, Hydrol. Processes, 20(10), 2171-2185, doi:10.1002/hyp.6201.

Forster, R. R., et al. (2013), Extensive liquid meltwater storage in firn within the Greenland ice sheet, Nat. Geosci., in press.

Fountain, A. G. (1989), The storage of water in, and hydraulic characteristics of, the firn of South Cascade Glacier, Washington State, U.S.A, Ann. Glaciol., 13, 69-75.

Hall, D. K., J. C. Comiso, N. E. DiGirolamo, C. A. Shuman, J. E. Box, and L. S. Koenig (2013), Variability in the surface temperature and melt extent of the Greenland ice sheet from MODIS, Geophys. Res. Lett., 40, 2114-2120, doi:10.1002/grl.50240.

Hanna, E., et al. (2013), Ice-sheet mass balance and climate change, Nature, 498(7452), 51-59, doi:10.1038/nature12238.

Harper, J., N. Humphrey, W. T. Pfeffer, J. Brown, and X. Fettweis (2012), Greenland ice-sheet contribution to sea-level rise buffered by meltwater storage in firn, Nature, 491(7423), 240-243, doi:10.1038/ nature 11566.

Herron, M. M., and C. C. Langway (1980), Firn densification: An empirical model, J. Glaciol., 25(93), 373-385.

Hörhold, M. W., S. Kipfstuhl, F. Wilhelms, J. Freitag, and A. Frenzel (2011), The densification of layered polar firn, J. Geophys. Res., 116, F01001, doi:10.1029/2009JF001630.

Howat, I. M., A. Negrete, T. A. Scambos, and T. Haran (2013), A highresolution elevation model for the Greenland Ice Sheet from combined stereoscopic and photoclinometric data.

Humphrey, N. F., J. T. Harper, and W. T. Pfeffer (2012), Thermal tracking of meltwater retention in Greenland's accumulation area, J. Geophys. Res., 117, F01010, doi:10.1029/2011JF002083.

Krabill, W. B. (2012), IceBridge ATM L2 icessn elevation, slope, and roughness, Boulder, Colo.: NASA DAAC at the National Snow and Ice Data Center.

Leuschen, C. (2012), IceBridge accumulation radar L1B geolocated radar echo strength profiles. April-May 2012, Boulder, Colo.: NASA DAAC at the National Snow and Ice Data Center.

Miège, C., R. R. Forster, J. E. Box, E. W. Burgess, J. R. McConnell, D. R. Pasteris, and V. B. Spikes (2013), Southeast Greenland high accumulation rates derived from firn cores and ground-penetrating radar, Ann. Glaciol., 54(63), 322-332, doi:10.3189/2013AoG63A358.

Nghiem, S. V., D. K. Hall, T. L. Mote, M. Tedesco, M. R. Albert, K. Keegan, C. A. Shuman, N. E. DiGirolamo, and G. Neumann (2012), The extreme melt across the Greenland ice sheet in 2012, Geophys. Res. Lett., 39, L20502, doi:10.1029/2012GL053611.

Nye, J. F. (1976), Water flow in glaciers: Jokulhlaups, tunnels, and veins, J. Glaciol., 17(76), 181-207.

Rennermalm, A. K., et al. (2013), Understanding Greenland ice sheet hydrology using an integrated multi-scale approach, Environ. Res. Lett., 8(1), 015017, doi:10.1088/1748-9326/8/1/015017.

Shepherd, A., et al. (2012), A reconciled estimate of ice-sheet mass balance, Science, 338(6111), 1183-1189, doi:10.1126/science.1228102.

van Angelen, J. H., J. T. M. Lenaerts, M. R. van den Broeke, X. Fettweis, and E. van Meijgaard (2013), Rapid loss of firn pore space accelerates $21 \mathrm{st}$ century Greenland mass loss, Geophys. Res. Lett., 40, 2109-2113, doi:10.1002/grl.50490.

van den Broeke, M., J. Bamber, J. Ettema, E. Rignot, E. Schrama, W. J. van de Berg, E. van Meijgaard, I. Velicogna, and B. Wouters (2009), Partitioning recent Greenland mass loss, Science, 326(5955), 984-986, doi:10.1126/science.1178176.

Zwally, H. J., W. Abdalati, T. Herring, K. Larson, J. Saba, and K. Steffen (2002), Surface melt-induced acceleration of Greenland ice-sheet flow, Science, 297(5579), 218-222, doi:10.1126/science.1072708. 